Richard Antony, Roswita Oktavianti: Pengaruh Kredibilitas Komunikator Terhadap Keputusan Pembelian (Survei Terhadap Produk AHHA Atta Halilintar)

\title{
Pengaruh Kredibilitas Komunikator Terhadap Keputusan Pembelian (Survei Terhadap Produk AHHA Atta Halilintar)
}

\author{
Richard Antony, Roswita Oktavianti \\ Richard.915160227@stu.untar.ac.id,Roswitao@fikom.untar.ac.id
}

Fakultas Ilmu Komunikasi Universitas Tarumanagara

\begin{abstract}
The credibility of a communicator is one of the factors for people to make purchasing decisions about a product. A communicator must have some ability in other words that the communicator must have the strength to compete, namely credibility and attractiveness. The research aims to examine the credibility of the communicator on the purchase decision of the AHHA Clothing Line Atta Halilintar product after watching YouTube Atta Halilintar. The independent variable in this study is the credibility of the communicator and the dependent variable is the purchase decision. The approach used in this study is quantitative descriptive. Research data were collected using non-probability sampling techniques or purposive sampling techniques. This study uses SPSS for Windows 23 test for Validity, Reliability, Hypothesis (simple linear analysis), T-test, Correlation Coefficient, and Determination Coefficient. Researchers obtain data that will be tested by distributing several questionnaires to all respondents, amounting to 100 respondents who have been determined and have been adjusted to the requirements in this study and respondents who represent the population of this study. The results obtained from the study showed that the communicator's credibility affected $29 \%$ in purchasing decisions while the remaining $71 \%$ was influenced by other factors. The relationship is positive, if the quality of the communicator's credibility increases, therefore the purchasing decision will also increase. And conversely, if the quality of the communicator's credibility decreases then the purchasing decision will also decrease.
\end{abstract}

Keywords: attractiveness, communicator credibility, purchase decision.

\begin{abstract}
Abstrak
Kredibilitas dari seorang komunikator merupakan salah satu faktor bagi masyarakat untuk mengambil keputusan pembelian terhadap sebuah produk. Seorang komunikator harus memiliki beberapa kemampuan dengan kata lain bahwa komunikator harus memiliki kekuatan untuk bersaing yaitu kredibilitas (credibility) dan daya tarik (attractiveness).Penelitian bertujuan untuk meneliti kredibilitas komunikator terhadap keputusan pembelian produk AHHA Clothing Line Atta Halilintar setelah menonton YouTube Atta Halilintar. Variabel independen yang berada dalam penelitian ini yaitu kredibilitas komunikator dan variabel dependen adalah keputusan pembelian. Pendekatan yang dipergunakan pada penelitian ini adalah deskriptif kuantitatif. Data penelitian dikumpulkan dengan menggunakan teknik non probability sampling atau teknik purposive sampling. Penelitian ini menggunakan alat uji SPSS for windows 23 untuk Uji Validitas, Reliabilitas, Hipotesis (analisis linier sederhana), Uji T, Koefisien Korelasi, dan Koefisien Determinasi. Peneliti memperoleh data-data yang akan diujikan dengan cara menyebarkan beberapa kuesioner kepada semua responden yang berjumlah 100 responden yang telah ditentukan dan telah disesuaikan dengan syarat-syarat pada penelitian ini dan responden yang mewakili dari populasi penelitian ini. Hasil yang diperoleh dari penelitian menunjukkan bahwa kredibilitas komunikator berpengaruh sebesar $29 \%$ pada keputusan pembelian sementara sisanya $71 \%$ dipengaruhi oleh faktor lain. Hubungan bersifat positif,apabila kualitas kredibilitas komunikator meningkat maka dari itu keputusan pembelian juga akan mengalami peningkatan. Dan sebaliknya, bila kualitas
\end{abstract}


kredibilitas komunikator menurun maka dari itu keputusan pembelian juga akan mengalami penurunan.

Kata Kunci: daya tarik, kredibilitas komunikator, keputusan pembelian.

\section{Pendahuluan}

Komunikator yang baik dapat menjadikan sikap calon pembeli mengalami perubahan dengan melalui proses secara psikologis yang dapat disebut internalisasi, sedangkan seorang konsumen yang telah memberikan respon bahwa komunikator tersebut menarik maka tujuan untuk persuasi akan terjadi melalui identifikasi. Internalisasi dapat terlaksana saat calon pembeli telah menerima posisi dari komunikator terhadap sebuah masalah seperti yang terdapat pada dirinya sendiri dan identifikasi dapat terjadi ketika konsumen melihat sesuatu yang mereka dapat anggap menarik dari diri seorang komunikator. Konsumen mengidentifikasi komunikator dan telah mengambil sikap, perilaku, minat, atau preferensi komunikator. Hal ini menunjukkan berarti calon pembeli telah memiliki pemikiran atau sebuah kesan tersendiri terhadap sesuatu yang sudah berkaitan dengan komunikator (Effendy dalam Dion dan Oktavianti, 2018).

Kredibilitas dari seorang komunikator merupakan salah satu pengaruh bagi masyarakat untuk mempertimbangkan keputusan pembelian terhadap produk tersebut. Terdapat beberapa ketentuan yang dimiliki oleh seorang komunikator yaitu kredibilitas (credibility) dan daya tarik (attractiveness), dimana atribut tersebut telah mengambil bagian terhadap efektivitas seorang komunikator. Kredibilitas (credibility) sendiri mengacu pada kecenderungan untuk percaya dengan seseorang. Kredibilitas sendiri mempunyai empat unsur yaitu harus dapat dipercaya (trustworthiness) dan mempunyai daya tarik (attractiveness). Komunikator dapat dianggap kredibel apabila ia jujur dalam mempresentasikan produk dengan sudut pandang yang objektif dan tidak berusaha untuk memanipulasi calon konsumen. Dengan daya tariknya serta keahliannya dalam membawakan suatu penilaian (review) produk akan mampu meyakinkan calon konsumen dalam mengambil keputusan pembelian (Rakhmat, 2012).

Proses pembelian yang rumit biasanya melibatkan beberapa keputusan, suatu keputusan melibatkan pilihan diantara beberapa alternatif tindakan atau perilaku, pada intinya walaupun pemasar sering mengacu ada pilihan antara produk, merek, dan tempat pembelian, proses pembelian juga biasanya dipengaruhi dengan hubungan baik antara produsen, proses pembelian konsumen melalui: (1) pengenalan masalah; (2) pencarian informasi; (3) evaluasi alternative; (4) keputusan pembelian; (5) perilaku pasca pembelian (Kotler dalam Samosir dan Prayoga, 2015).

Muhammad Attamimi Halilintar atau lebih dikenal dengan nama Atta Halilintar berhasil membuktikan kepada publik bahwa kesuksesannya sebagai YouTuber membuatnya dipandang dunia. Di awal membuat video YouTube, Atta memulai dengan konten-konten vlog atau lebih sering disebut dengan daily vlog, yaitu menceritakan aktivitasnya dalam sehari ke sebuah video dan mengunggahnya ke channel YouTube pribadinya. Beberapa waktu lalu anggota Gen Halilintar ini sempat menduduki peringkat pertama YouTuber nomor 1 di Asia Tenggara. Kini Atta Halilintar berhasil mencetak rekor baru. Atta Halilintar sukses menorehkan rekor jumlah subscriber hingga 15 juta. Dengan jumlah tersebut, Atta Halilintar masuk sebagai YouTuber di Asia dengan jumlah subscriber terbanyak. Kepastian Atta Halilintar meraih 15 juta subscriber diketahui melalui akun instagram. Tampak Atta 
Richard Antony, Roswita Oktavianti: Pengaruh Kredibilitas Komunikator Terhadap Keputusan Pembelian (Survei Terhadap Produk AHHA Atta Halilintar)

Halilintar mengunggah foto memegang laptop dengan tulisan jumlah subscriber di angka 15.00.254. (Diakses : https://www.brilio.net/selebritis/atta-halilintar-youtuberno-1-di-asia-tembus-15-juta-subscriber-190510t.html).

\section{Metode Penelitian}

Gambar 1: Variabel X dan Variabel Y

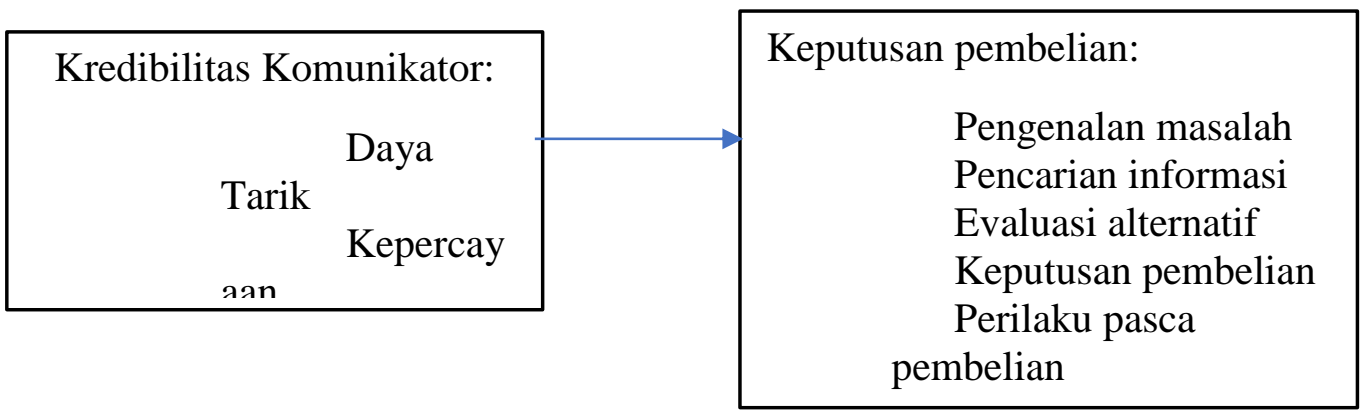

Pendekatan yang digunakan dalam penelitian ini adalah kuantitatif, yaitu pendekatan ilmiah terhadap pengambilan keputusan. Menurut Sugiyono, penelitian kuantitatif merupakan sebuah penelitian yang cenderung berupa angka-angka dan analisis dengan menggunakan statistik(Agusta dan Susanto, 2013).

Populasi dalam penelitian ini berupa konsumen dan calon konsumen yang berada di Jakarta Selatan. Menurut Badan Pusat Statistik, wilayah terpadat yang berada di urutan ketiga dalam data kepadatan penduduk DKI Jakarta pada tahun 2017 adalah Jakarta Selatan yang memiliki 15.763 jiwa per km persegi.Penulis mengambil wilayah Jakarta Selatan karena bintang YouTube Muhammad Attamimi Halilintar membuka gerai Clothing Line AHHA pertamanya di Pondok Pinang, Jakarta Selatan.

Penulis menggunakan accidental sampling atau teknik penarikan purposif yang didasarkan pada sebuah karakteristik tertentu yang dianggap mempunyai sangkut paut dengan karakteristik populasi yang sudah diketahui sebelumnya. Penelitian ini akan mengambil unit sampel yang terbatas hanya pada konsumen dan calon konsumen produk AHHA Atta Halilintar saja.

Penentuan jumlah sampel dalam penelitian ini menggunakan rumus Slovin (Sugiyono, 2006) yang bertujuan untuk menentukan banyaknya sampel yang akan digunakan, sebagai berikut:

$$
n=\frac{N}{1+N \cdot \mathrm{e}^{2}}
$$

Dimana:

$\mathrm{n}=$ Jumlah sampel

$\mathrm{N}=$ Jumlah populasi ( 150 )

$\mathrm{e}=$ Nilai toleransi sebesar $10 \%$ atau 0.1

Berdasarkan rumus Slovin diatas maka sampel yang digunakan oleh penulis adalah:

$$
\begin{aligned}
& \mathrm{n}=\frac{150}{1+150.0,1^{2}} \\
& \mathrm{n}=\frac{150}{1+150.0,01}
\end{aligned}
$$




$$
\begin{array}{r}
\mathrm{n}=\quad \frac{150}{1+1,5} \\
\mathrm{n}=\quad \frac{150}{2,5} \\
\mathrm{n}=\quad 60 \text { (dibulatkan menjadi } 100)
\end{array}
$$

Teknik pengumpulan data yang telah digunakan oleh peneliti pada penelitian ini yaitu penggunaan beberapa data primer berupa angket atau kuesioner. Angket atau kuesioner yang telah digunakan dalam penelitian ini adalah kuesioner tertutup, responden akan diminta untuk mengisi kuesioner berupa pilihan jawaban yang sesuai menurut mereka.

\section{Hasil Temuan dan Diskusi}

Setelah mendapatkan data lalu data diproses melalui proses pengolahan data dengan menggunakan Program SPSS Ver.23 diperoleh hasil uji validitas dengan $R_{\text {hitung }}$ seperti yang ditunjukan tabel 1 .

Tabel 1: Hasil Uji Validitas Variabel X (Kredibilitas Komunikator)

\begin{tabular}{lccc}
\hline $\mathbf{X}$ & $\begin{array}{c}\text { Corrected } \\
\text { Item-Total } \\
\text { Correlation }\end{array}$ & $\begin{array}{c}\text { Nilai } \\
\text { Patokan }\end{array}$ & Keterangan \\
\hline P1 & 0,556 & 0,2 & Valid \\
\hline P2 & 0,695 & 0,2 & Valid \\
\hline P3 & 0,597 & 0,2 & Valid \\
\hline P4 & 0,608 & 0,2 & Valid \\
\hline P5 & 0,608 & 0,2 & Valid \\
\hline P6 & 0,675 & 0,2 & Valid \\
\hline P7 & 0,621 & 0,2 & Valid \\
\hline P8 & 0,543 & 0,2 & Valid \\
\hline
\end{tabular}

Sumber: Hasil Pengolahan Data SPSS Versi 23

Tabel 1. menunjukkan 8 buah butir pernyataan yang dimiliki variabel Kredibilitas Komunikator (Variabel X) memiliki nilai Corrected Item-Total Correlation di atas 0,2 atau $\mathrm{R}_{\text {hitung }}$ lebih besar dari $\mathrm{R}_{\text {tabel. }}$. Artinya bahwa angka-angkat pernyataan tersebut dinyatakan memiliki nilai valid dan dapat digunakan dalam melakukan penelitian ini.

Tabel 2: Hasil Uji Validitas Variabel Y (Keputusan Pembelian)

\begin{tabular}{cccc}
\hline $\mathbf{Y}$ & $\begin{array}{c}\text { Corrected } \\
\text { Item-Total } \\
\text { Correlation }\end{array}$ & $\begin{array}{c}\text { Nilai } \\
\text { Patokan }\end{array}$ & Keterangan \\
\hline P1 & 0,485 & 0,2 & Valid \\
\hline P2 & 0,714 & 0,2 & Valid \\
\hline P3 & 0,508 & 0,2 & Valid \\
\hline P4 & 0,778 & 0,2 & Valid \\
\hline P5 & 0,811 & 0,2 & Valid \\
\hline P6 & 0,795 & 0,2 & Valid \\
\hline P7 & 0,752 & 0,2 & Valid \\
\hline
\end{tabular}


Richard Antony, Roswita Oktavianti: Pengaruh Kredibilitas Komunikator Terhadap Keputusan Pembelian (Survei Terhadap Produk AHHA Atta Halilintar)

\begin{tabular}{llll}
\hline P8 & 0,768 & 0,2 & Valid \\
\hline
\end{tabular}

Sumber: Hasil Pengolahan Data SPSS Versi 23

Tabel 2. menunjukkan 8 buah butir pernyataan yang dimiliki variabel Keputusan Pembelian (Variabel Y) memperoleh hasil nilai Corrected Item-Total Correlation di atas $0,2 \mathrm{R}_{\text {hitung }}$ yang lebih besar dari $\mathrm{R}_{\text {tabel }}$. Artinya bahwa item-item dari semua pernyataan tersebut dinyatakan valid dan dapat digunakan dalam meneliti penelitian ini.

Tabel 3: Hasil Uji Reliabilitas Variabel X (Kredibilitas Komunikator)

\begin{tabular}{|l|c|}
\hline $\begin{array}{l}\text { ronbach's } \\
\text { Alpha }\end{array}$ & of Items \\
\hline 0,862 & 8 \\
\hline
\end{tabular}

Sumber: Hasil Pengolahan Data SPSS Versi 23

Tabel 3. menunjukkan 8 buah total pernyataan pada variabel X (Kredibilitas Komunikator) dengan nilai Cronbach's Alpha yang diperoleh sebesar 0,862 yang memiliki arti dimana variabel Kredibilitas Komunikator memiliki instrumen yang menunjukkan hasil dari instrumen tersebut yang reliabel karena instrument tersebut memiliki nilai Cronbach's Alpha>0,6.

Tabel 4: Hasil Uji Reliabilitas Variabel Y (Keputusan Pembelian)

\begin{tabular}{|l|c|}
\hline $\begin{array}{l}\text { ronbach's } \\
\text { Alpha }\end{array}$ & of Items \\
\hline 0,906 & 8 \\
\hline
\end{tabular}

Sumber: Hasil Pengolahan Data SPSS Versi 23

Tabel 4. menunjukkan 8 buah butir pernyataan variabel Y (Keputusan Pembelian) yang memiliki nilai Cronbach's Alpha yang diperoleh sebesar 0,906 yang memiliki arti dimana variabel Keputusan Pembelian menunjukkan instrumen reliabel karena nilai Cronbach's Alpha> 0,6.

Gambar 1: Diagram Sumbu Diagonal Uji Normalitas Normal P-P Plot of Regression Standardized Residual

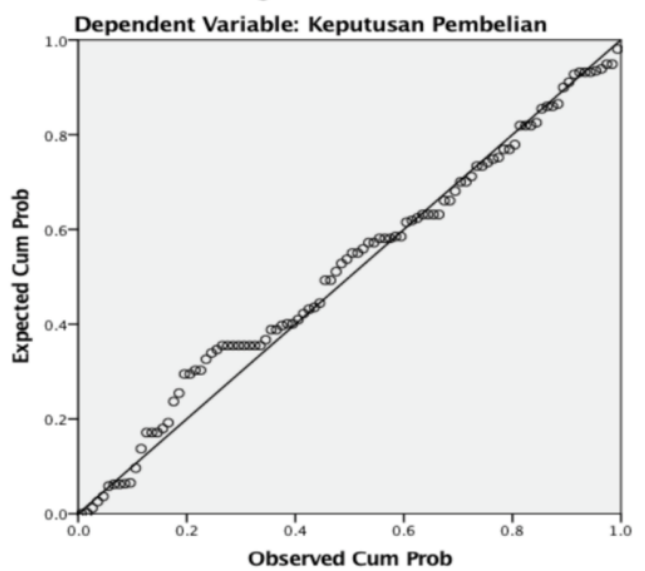

Sumber: Hasil Pengolahan Data SPSS Versi 23.0 
Pada Gambar 1.Data menunjukkan data yang tersebar di daerah sekitar garis diagonal dengan arah yang menunjukkan data hubungan koefisien positif (koefisien 0 s/d 1) dan mengikuti arah dari garis diagonal, maka model regresi yang dimiliki dengan variabel bebas kredibilitas komunikator dan variabel terikat keputusan pembelian adalah keduanya memiliki hubungan distribusi normal dan telah teruji memenuhi uji normalitas.

Tabel 5: Hasil Uji Koefisien Korelasi

Model Summary

\begin{tabular}{lcccc}
\hline Model & $\mathrm{R}$ & Square & isted R Square & $\begin{array}{r}\text { Error of the } \\
\text { Estimate }\end{array}$ \\
\hline 1 & $39 \mathrm{a}$ & .290 & .283 & 4.254 \\
\hline & Sumber: Hasil Pengolahan Data SPSS Versi 23.0
\end{tabular}

Pada Tabel 5. menunjukkan hasil dari uji koefisien korelasi (R) dari variabel (Kredibilitas Komunikator) terhadap variabel (Keputusan Pembelian) dalam penelitian ini sebesar 0,539. Hasil yang ditunjukkan uji koefisien korelasi berada di daerah rentang 0,40-0,599 maka dapat ditarik kesimpulan bahwa antara kredibilitas komunikator dan keputusan pembelian terdapat hubungan dan sifat yang dimiliki hubungan tersebut adalah sedang.

Tabel 6: Hasil Uji Koefisien Determinasi

Model Summary

\begin{tabular}{ccccc}
\hline Model & $\mathrm{R}$ & Square & $\begin{array}{c}\text { Adjusted } \mathrm{R} \\
\text { Square }\end{array}$ & $\begin{array}{c}\text { Error of the } \\
\text { Estimate }\end{array}$ \\
\hline 1 & 39a & .290 & .283 & 4.254 \\
\hline \multicolumn{4}{c}{ Sumber: Hasil Pengolahan Data SPSS Versi 23.0}
\end{tabular}

Tabel 6.menunjukkan hasil dari koefisien determinasi dengan cara melihat angka yang berada pada R Square. Hasil dari R Square adalah 0,290. Hal ini dapat dikatakan kemampuan dari variabel independen (Kredibilitas Komunikator) dalam mempengaruhi variabel dependen (Keputusan Pembelian) memiliki nilai sedang karena mendapatkan nilai koefisien determinasi yang berada di antara nol sampai satu yaitu 0,290. Berdasarkan hasil koefisien determinasi di atas, dapat juga dikatakan bahwa nilai keputusan pembelian dipengaruhi sebesar $29 \%$ oleh kredibilitas komunikator, sementara sisanya $71 \%$ dipengaruhi oleh variabel-variabel lain.

Tabel 7: Hasil Uji Analisis Regresi Linier Sederhana

\begin{tabular}{|c|c|c|c|c|c|c|}
\hline & \multirow[b]{2}{*}{ Model } & \multicolumn{2}{|c|}{$\begin{array}{l}\text { Instandardized } \\
\text { Coefficients }\end{array}$} & \multirow{2}{*}{$\begin{array}{l}\text { andardized } \\
\text { Coefficients } \\
\text { Beta }\end{array}$} & \multirow[t]{2}{*}{$\mathrm{t}$} & \multirow[t]{2}{*}{ ig. } \\
\hline & & $\mathrm{B}$ & . Error & & & \\
\hline \multirow[t]{2}{*}{1} & (Constant) & t.195 & .176 & & .469 & 300 \\
\hline & $\begin{array}{r}\text { Kredibilitas } \\
\text { Komunik }\end{array}$ & 608 & 096 & .539 & .327 & 300 \\
\hline
\end{tabular}

Sumber: Hasil Pengolahan Data SPSS Versi 23.0 
Richard Antony, Roswita Oktavianti: Pengaruh Kredibilitas Komunikator Terhadap Keputusan Pembelian (Survei Terhadap Produk AHHA Atta Halilintar)

Tabel 7. menunjukkan persamaan tersebut dapat diartikan bahwa, nilai sebesar 14,195 menyatakan nilai konstanta dari fungsi regresi yang menunjukan bahwa jika ternyata tidak ada kenaikan variabel X (Kredibilitas Komunikator), maka variabel Y (Keputusan Pembelian) akan dapat mencapai 14,195. Setiap terdapat ada penambahan 1 angka atau terdapat perubahan variabel X (Kredibilitas Komunikator), maka akan berpengaruh kepada variabel Y (Keputusan Pembelian) yang akan mengalami peningkatan sebesar 0,608. Hal ini dapat dikatakan hasil uji $\mathrm{T}$ pada variabel $\mathrm{X}$ adalah Ho ditolak dan Ha diterima, yang artinya terdapat pengaruh kredibilitas komunikator terhadap keputusan pembelian.

\section{Simpulan}

Terdapat pengaruh kredibilitas komunikator terhadap keputusan pembelian sebesar $29 \%$ sedangkan $71 \%$ dipengaruhi faktor lainnya. Kredibilitas komunikator memiliki hubungan yang sedang terhadap keputusan pembelian. Hubungan juga bersifat positif artinya semakin meningkat kredibilitas komunikator maka nilai yang ada pada keputusan pembelian juga akan meningkat. Dan juga sebaliknya bila nilai kredibilitas komunikator menurun maka keputusan pembelian juga akan mengalami penurunan.

\section{Ucapan Terima Kasih}

Ucapan terima kasih kepada seluruh responden penelitian dan teman-teman perkuliahan yang memberikan semangat, waktu dan yang telah memberikan semangat dan menemani selama berlangsungnya atau berjalannya proses pembuatan penelitian ini berlangsung dari awal sampai selesai dengan akhirnya pembuatan dari artikel jurnal ini.

\section{Daftar Pustaka}

Agusta, Leonando., E.M. Susanto. (2013). Pengaruh Pelatihan dan Motivasi Kerja Terhadap Kinerja Karyawan CV Haragon Surabaya. Jurnal AGORA.

Dion, Calvin dan Oktavianti, Roswita. (2018). Komunikasi Persuasif Public Speaker Pada Audiens Berbeda Negara (Studi Fenomenologi Master Of Ceremony Pada Audiens China dan Amerika). Jurnal Koneksi Universitas Tarumanagara. Vol 2. No 2.

Rakhmat, Jalaludin. (2012). Psikologi Komunikasi. Bandung: PT. Remaja Rosda Karya.

Samosir, C.B.H., Prayoga, A.B. (2015). Jurnal Pengaruh Persepsi Harga dan Promosi Terhadap Keputusan Pembelian Konsumen Produk ENERVON-C. Jurnal Ilmiah Manajemen dan Bisnis.

Sugiyono. (2006). Metode Penelitian Kuantitatif, Kualitatif, dan R\&D. Bandung: Alfabeta, CV.

Sugiyono. (2017). Metode Penelitian Kuantitatif, Kualitatif, dan R\&D. Bandung : Alfabeta, CV.

https://www.brilio.net/selebritis/atta-halilintar-youtuber-no-1-di-asia-tembus-15-jutasubscriber-190510t.html 